\title{
EVALUATION OF STABILISED CELLS IN THE INDIRECT HAEMAGGLUTINATION TEST FOR ECHINOCOCCOSIS
}

\author{
S. C. PARIJA AND N. ANANTHAKRISHNAN* \\ Departments of Microbiology and *Surgery, Jawaharlal Institute of Postgraduate \\ Medical Education and Research, Pondicherry 605 006, India
}

\begin{abstract}
Summary. We have evaluated the use of sheep red-blood cells stabilised in various ways in indirect haemagglutination tests on the sera of 21 surgically confirmed cases of echinococcosis, and on control sera. Tests with Double-Aldehyde-Stabilised cells - treated sequentially with pyruvic aldehyde, tannic acid and glutaraldehyde - were more sensitive than tests with the cells treated only with formaldehyde, glutaraldehyde or pyruvic aldehyde, and subsequently tanned.
\end{abstract}

\section{INTRODUCTION}

The indirect haemagglutination test (IHA), by virtue of its simplicity, specificity and sensitivity, is being increasingly used by many workers for the serodiagnosis of echinococcosis (Iacona, Pini and Vicari, 1980; Chemtai, Bowry and Ahmad, 1981). Red blood cells stabilised either by formaldehyde, glutaraldehyde or pyruvic aldehyde are routinely used in the test in different laboratories. Formalised cells have been used by Parodi (1960), Mandras and Addis (1960), Allain and Kagan (1961) and Chordi et al. (1962) (all cited from Kagan, 1968), whereas glutaraldehyde-treated cells have been used by Ben-Ismail et al. (1980).

Earlier, Ling (1961) showed a superiority for pyruvic aldehyde and glutaraldehyde over other reagents in stabilisation of the cells. Later, Farshy and Kagan (1972) observed that cells stabilised by a combination of these two aldehydes separated by a tanning procedure were better than cells stabilised by treatment with a single aldehyde for use in IHA for malaria. The present study was undertaken to evaluate the use of Double Aldehyde Stabilised (DAS) cells and of cells stabilised by treatment with formaldehyde, pyruvic aldehyde or glutaraldehyde in an IHA test for echinococcosis.

\section{Materials AND Methods}

Antigen. Hydatid-cyst fluid was obtained from patients at surgical operation and was processed by the method of Arabatzis and Papapanagiotou (1963).

Sera. Blood samples were collected from 21 surgically confirmed cases of echinococcosis in our hospital during the period 1981-83 and the sera separated. Negative control sera were obtained from 25 normal healthy persons. All the sera were stored at $-20^{\circ} \mathrm{C}$ until required.

Sheep red blood cells $(S R B C$ ). Blood was collected into Alsever's solution, the cells thrice 
washed in phosphate-buffered saline $0 \cdot 15 \mathrm{M}, p \mathrm{H} 7 \cdot 2$ (PBS) and treated with the stabilising agent within $48 \mathrm{~h}$.

Stabilisation with formaldehyde. The method of Fulthrope et al. (1961, cited by Herbert, 1978) was used. To a suspension of SRBC (10 ml of packed cells in $500 \mathrm{ml}$ of PBS), $50 \mathrm{ml}$ of formalin (aqueous formaldehyde, $40 \% \mathrm{w} / \mathrm{v}$ ) was added slowly from a burette, over a period of 30 min. The mixture was left overnight at $4^{\circ} \mathrm{C}$, and a further $50 \mathrm{ml}$ of formalin was then added in one lot. Twenty-four hours later the preserved cells were washed thrice in PBS and stored at $4^{\circ} \mathrm{C}$ as a $50 \% \mathrm{v} / \mathrm{v}$ suspension in a 1 in 200 dilution of formalin in PBS.

Stabilisation with glutaraldehyde. The suspension was prepared as described by Avrameas, Taudou and Chuilon (1969). Briefly, $10 \mathrm{ml} \mathrm{of} 5 \% \mathrm{v} / \mathrm{v}$ aqueous glutaraldehyde was added to $1 \mathrm{ml}$ of a $10 \%$ suspension of SRBC in PBS, and the mixture was stirred by a magnetic stirrer for $4 \mathrm{~h}$ at room temperature. The cells were washed thrice in PBS and stored at $4{ }^{\circ} \mathrm{C}$ as a $30 \% \mathrm{v} / \mathrm{v}$ suspension in PBS.

Stabilisation with pyruvic aldehyde. The method was modified from that of Farshy and Kagan (1972). A reaction mixture of the following substances, added in the order given, was prepared and subsequently kept in the cold: $1.7 \% \mathrm{NaCl}, 12 \mathrm{ml} ; 40 \% \mathrm{v} / \mathrm{v}$ aqueous pyruvic aldehyde, $4 \mathrm{ml} ; 1.0 \% \mathrm{Na}_{2} \mathrm{CO}_{3}, 35 \mathrm{ml}$; Sorensen's phosphate buffer $(p \mathrm{H} 7.2) 7 \mathrm{ml}$. To this, $10 \mathrm{ml}$ of a $50 \%$ suspension of SRBC was added. The mixture was stirred for $30 \mathrm{~min}$ and stored for $24 \mathrm{~h}$ at $4^{\circ} \mathrm{C}$. The cells were then washed thrice in PBS and stored in this as a $2.5 \% \mathrm{v} / \mathrm{v}$ suspension at $4^{\circ} \mathrm{C}$.

Double-aldehyde stabilisation (DAS) was performed as described by Farshy and Kagan (1972). The cells were first stabilised with pyruvic aldehyde (as above). To a $2.5 \%$ suspension of these an equal volume of cold tannic acid 1 in 25000 in PBS was added and the mixture kept at $4^{\circ} \mathrm{C}$ for $30 \mathrm{~min}$. The cells were then washed thrice in PBS and made up to a $4 \%$ suspension in the same diluent. To this was added an equal volume of $2 \% \mathrm{v} / \mathrm{v}$ aqueous glutaraldehyde in PBS over a magnetic stirrer which was run for $2 \mathrm{~h}$. The cells were then washed thrice with PBS and stored as a $50 \% \mathrm{v} / \mathrm{v}$ suspension in this diluent.

The IHA test. Cells treated with formaldehyde, glutaraldehyde or pyruvic aldehyde were treated with tannic acid before being sensitised with antigen (Herbert, 1978). With DAS cells this step was omitted because the cells had been tanned during stabilisation.

The optimum sensitising dose of antigen was determined for each type of sensitised cells by chequer-board titration with known positive and negative sera. The values obtained were: 1 in 16 for formaldehyde-, 1 in 8 for glutaraldehyde-, 1 in 8 for pyruvic-aldehyde-treated cells, and 1 in 16 for DAS cells. The IHA test was performed as described by Herbert (1978).

\section{RESULTS}

The table shows the IHA titres obtained with the four types of stabilised SRBC. With 19 of the 21 sera from patients with echinococcosis, the DAS cells gave titres 2-4 times higher than those obtained with any other type of cell. We concluded from the results obtained with sera from persons with no evidence of echinococcosis that a titre of 128 or more could be taken as evidence of this disease. Such a titre was given by 19 sera with DAS cells but by only 16 with formaldehyde-treated and 15 with pyruvic aldehyde- and glutaraldehyde-treated cells.

\section{Discussion}

IHA tests are inexpensive and easy to perform, and can be read without errors of subjectivity. This makes them potentially useful for investigations in areas endemic for echinococcosis (Lewis, Koss and Kerstein, 1975) such as the one in which we work (Parija et al., 1983).

When used for the diagnosis of malaria (Kagan, 1972), the sensitivity of the test depended upon the method of stabilising the cells and the antigen employed (Farshy 
TABLE

Results of IHA tests on the sera of confirmed cases of echinococcosis and normal persons

\begin{tabular}{|c|c|c|c|c|}
\hline \multirow[b]{2}{*}{ Serum no. } & \multicolumn{4}{|c|}{$\begin{array}{l}\text { Titre of haemagglutination of } \\
\text { sheep RBC stabilised with }\end{array}$} \\
\hline & $\begin{array}{l}\text { Formal- } \\
\text { dehyde }\end{array}$ & $\begin{array}{l}\text { Pyruvic } \\
\text { aldehyde }\end{array}$ & $\begin{array}{l}\text { Glutar- } \\
\text { aldehyde }\end{array}$ & $\begin{array}{l}\text { Double } \\
\text { aldehyde }\end{array}$ \\
\hline \multicolumn{5}{|l|}{$\begin{array}{l}\text { Cases of } \\
\text { echinococcosis }\end{array}$} \\
\hline 1 & 128 & 128 & 128 & 256 \\
\hline 2 & 32 & 8 & 16 & 128 \\
\hline 3 & 256 & 256 & 256 & 1024 \\
\hline 4 & 128 & 128 & 128 & 512 \\
\hline 5 & 32 & 16 & 8 & 8 \\
\hline 6 & 128 & 128 & 128 & 256 \\
\hline 7 & 128 & 128 & 128 & 256 \\
\hline 8 & 256 & 128 & 128 & 512 \\
\hline 9 & 128 & 128 & 128 & 256 \\
\hline 10 & 128 & 128 & 128 & 256 \\
\hline 11 & 512 & 256 & 256 & 1024 \\
\hline 12 & 128 & 128 & 128 & 256 \\
\hline 13 & 8 & 8 & 16 & 32 \\
\hline 14 & 64 & 32 & 16 & 128 \\
\hline 15 & 128 & 128 & 128 & 256 \\
\hline 16 & 32 & 16 & 32 & 128 \\
\hline 17 & 128 & 32 & 64 & 128 \\
\hline 18 & 256 & 128 & 128 & 512 \\
\hline 19 & 256 & 256 & 128 & 512 \\
\hline 20 & 256 & 256 & 256 & 1024 \\
\hline 21 & 128 & 128 & 128 & 256 \\
\hline \multicolumn{5}{|l|}{ Normal persons* } \\
\hline 1 & 16 & 16 & 32 & 32 \\
\hline 2 & 32 & 16 & 16 & 16 \\
\hline 3 & 32 & 32 & 32 & 32 \\
\hline 4 & 16 & 32 & 32 & 32 \\
\hline 5 & 32 & 32 & 16 & 16 \\
\hline 6 & 16 & 16 & 16 & 32 \\
\hline 7 & 16 & 16 & 16 & 16 \\
\hline 8 & 16 & 16 & 32 & 32 \\
\hline 9 & 64 & 32 & 64 & 64 \\
\hline 10 & 16 & 32 & 32 & 64 \\
\hline
\end{tabular}

*Sera from another 15 normal persons showed a titre of 8 or less with all the stabilised cells.

and Kagan, 1972). Coupling agents such as aldehydes not only stabilise the cells but react with free amino groups, sulphydryl groups and, to some extent, imidazole groups, rendering the surface of the $\mathrm{RBC}$ more anionic and so facilitating the attachment of protein antigens to them (Farshy and Kagan, 1972). The experience of these authors with malaria, and of Jagannath and Sengupta (1981) with leprosy, showed that the use of DAS cells greatly increased the sensitivity of the IHA tests. Our experience with echinococcosis is in conformity with this; in tests with DAS cells we obtained a diagnostic titre in $90.4 \%$ of surgically confirmed cases.

\section{REFERENCES}

Arabatzis G, Papapanagiotou J 1963 Laboratory tests in hydatid disease: a comparison of the indirect haemagglutination, complement-fixation and intradermal test. Bulletin of the World Health Organization 28:266-268. 
Avrameas S, Taudou B, Chuilon S 1969 Glutaraldehyde, cyanuric chloride and tetra-azotized o-dianisidine as coupling reagents in the passive hemagglutination test. Immunochemistry 6:67-76.

Ben-Ismail R, Carme B, Niel G, Gentilini M 1980 Non-specific serological reactions with Echinococcus granulosus antigens: Role of anti- $\mathrm{P}_{1}$ antibodies. American Journal of Tropical Medicine and Hygiene 29:239-245.

Chemtai A K, Bowry T R, Ahmad Z 1981 Evaluation of five immunodiagnostic techniques in echinococcosis patients. Bulletin of the World Health Organization 59:767-772.

Farshy D C, Kagan I G 1972 Use of stable sensitized cells in indirect microhemagglutination test for malaria. American Journal of Tropical Medicine and Hygiene 21:868-872.

Herbert W J 1978 Passive haemagglutination with special reference to the tanned cell technique. In: Weir D M (ed) Handbook of experimental immunology, 3rd edn, Chapter 20. Blackwell, Oxford, p 1.

Iacona A, Pini C, Vicari G 1980 Enzyme-linked immunosorbent assay (ELISA) in the serodiagnosis of hydatid disease. American Journal of Tropical Medicine and Hygiene 29:95-102.

Jagannath C, Sengupta D N 1981 Serology of leprosy. I. Indirect haemagglutination test with stabilized sensitized red cells. Leprosy in India 53:507-512.

Kagan I G 1968 A review of serological tests for the diagnosis of hydatid disease. Bulletin of the World Health Organization 39:25-37.

Kagan I G 1972 Evaluation of the indirect hemagglutination test as an epidemiologic technique for malaria. American Journal of Tropical Medicine and Hygiene 21:683-689.

Lewis J W, Koss N, Kerstein M D 1975 A review of echinococcal disease. Annals of Surgery 181:390-396.

Ling N R 1961 The attachment of proteins to aldehyde-tanned cells. British Journal of Haematology 7:299-302.

Parija S C, Rao R S, Badrinath S, Sengupta D N 1983 Hydatid disease in Pondicherry. Journal of Tropical Medicine and Hygiene 86:113-115. 